\title{
World War and Revolution: The Spring and Springs of Democracy
}

Pasi Ihalainen, The Springs of Democracy. National and Transnational Debates on Constitutional Reform in the British, German, Swedish and Finnish Parliaments, 1917-1919. Finnish Literature Society (SKS) Studia Fennica. 2017. 586 pages. ISBN 9789522229182.

\section{Bo Stråth, University of Helsinki}

From a methodological perspective that combines Reinhart Koselleck's conceptual history and the Cambridge speech act school, Ihalainen explores the breakthrough of democracy in Britain, Germany, Sweden and Finland after the First World War. The focus is on the constitutional debates in the parliaments and in major newspapers. The broader framework of the monograph is the wave of claims for democracy that followed in the wake of the war and the two Russian revolutions, which were closely connected to the war. The war experiences became a force that mobilized and politicized the public in an unprecedented way, and this politicisation called for extended political participation. The European societies, exhausted by the war, began to reconsider older patterns of loyalty and allegiance, identities and imaginaries of political order and participation. The sacrifices of the masses for the war efforts required concessions by the ruling elites in terms of political influence. The mobilization of the populations for the war efforts produced mass societies of a new kind, which, in turn, resulted in new kinds of social unrest confronting established patterns of political legitimacy.

Ihalainen is writing from the perspective of social constructivism but not in a strong deterministic sense where the language is causative. His approach confronts teleological goal-driven views. His combination of a softer form of social constructivism and conceptual history is convincing. Constitutions and the nation states they frame are in his perspective not natural units but the outcome of long-term processes of discursive mobilisation of populations for nation and state building. Ihalainen's innovative contribution to the debate is that he transcends the national framework of analysis. He demonstrates how such processes historically took place in inter- and transnational interaction between related political cultures, centres and peripheries. Existing investigations of the constitutional reforms in Europe around 1920 have focused on the course of events in national cases without studying the wider European conceptual foundations of the history of events.

Willibald Steinmetz (1993, 2007) and Kari Palonen (2008, 2010, 2012, 2014) are pioneers in the application of conceptual history on the study of parliamentarian orders. Ihalainen develops their research in new directions. In methodological terms his approach deals with the role of the political lan- 
guage in the major transformation from authoritarianism to democracy between 1917 and 1920 by means of discourse analysis and conceptual history. The approach goes beyond the analysis of the historical semantics of key political concepts in the methodology of Begriffsgeschichte. With parliamentary records and newspaper articles as key source material the book analyses the wave of nationally multi-sited and transnationally interconnected debates on constitutional reform that emerged and spread over Europe from 1917 on in response to growing war-weariness and under inspiration of the Russian revolution. The debates dealt with the political implications of the war and the promises and threats that the Russian revolution provoked. A new semantic field with key concepts like democracy, people, nation, and parliamentarianism emerged. The author analyses the contentious meanings of these and adjacent terms suggested from both the left and the right spectrum of politics as they emerged in parliamentary debates and in a selection of conservative, liberal and socialist party newspapers in the four countries.

Ihalainen connects to a recent research trend which questions the conventional narrative on democracy as an enlightenment heritage which slowly but implacably broke through in the nineteenth century, and argues that Europe on the eve of 1914 was basically conservative and authoritarian. Furthermore, the break-through of democracy was far from general. Authoritarianism and totalitarianism competed with democracy as a model of government at least until 1945, in Eastern Europe longer. The Weimar republic demonstrates how fragile what seemed to be a break-through in 1917-1919 really was.

More is at stake than the establishment of the connection between the war and the "break-through" of democracy, however. What can be seen as a formative moment in European history in the wake of the world war and the two Russian revolutions challenges the master narrative called modernisation, which American social sciences disseminated in the 1960s building a straight connection between democracy and capitalism as well as between enlightenment philosophy and democracy across the gap of the world wars. The Springs of Democracy opens up this gap again and demonstrates that the condensed period between 1917 and 1920 was caesural. Not the enlightenment philosophy and the impression of the French revolution but the immediate experiences of the world war and the Russian revolutions are the catalyst in the shift from authoritarian regimes to democracy, which soon after the breakthrough against the backdrop of social and economic post-war crisis in several cases shifted back to authoritarianism again, yes, even totalitarianism of a new kind. Ihalainen demonstrates how fragile and far from stable the democratic breakthrough really was.

The spring of 1919 brought promises of a new time and the beginning of a global democratic era. Woodrow Wilson and Lenin, the masters of the competing triumphing liberal and socialist ideologies at the time agreed on democracy as the label of the new era. The only disagreement between them was 
whether the colonies should be part of the new order or not. Later more substantial disagreement emerged about the definition of democracy as we know.

The focus of the book is on the contention around key concepts like democracy, people, and parliamentarism, where defenders of the old order preferred to talk about the people instead of democracy, and struggled for linking it to imaginaries of national cohesion with the king as the primary representative of the people. The voices for the new order confronted the argument about national unity emphasizing interest contention as the core of democracy. Their point of reference was the parliament understood in new ways as a new kind of political power centre. The author elaborates on the discursive struggle between socialism, conservatism and liberalism in rich detail.

The radicalization of the political debate in the wake of the Russian revolution and the collapse of the European empires meant also the inclusion of the women in the definition of general or universal suffrage. Before the First World War general suffrage including the women existed only in New Zealand, Finland, and Norway. Ihalainen's argument for excluding this issue from the analysis ( $\mathrm{p} 42$ ) is not comprehensible, however, and astonishing in a for the rest convincing analysis. The decision to leave technical questions concerning elections such as the limits of suffrage outside the study is reasonable but the question of female suffrage is a much more principle question than just a technical issue.

The methodology of conceptual history focuses on the contentious discursive struggles and the disagreements about the key concepts of the debate. The disagreements about the meaning of concepts like democracy and people were the motor of the politics. The discursive tensions made the outcome difficult to predict and the future open. Conceptual history provides a different understanding of politics than approaches which focus on the institutions rather than the political language, and on the causes and consequences of political change in the past, which tend to confirm what happened rather than emphasizing the alternatives and the openness of historical processes. Conceptual history brings openness.

The comparison of the debates and conflicts around the key concepts in the four languages is convincing. At least the young Koselleck argued that comparison between languages is impossible because the meaning of political key concepts is so different. He referred to the impossibility of comparing citoyen with Staatsbürger because they represent very different histories. The conventional understanding today among conceptual historians is that exactly because they are different they are a rich source of historical inquiry. They open up for fruitful questions about why the meaning is different and how it became so. There is no translation 1:1 but exactly the gaps that the approximations constitute is the space where interesting histories take place. Ihalainen demonstrates the validity of this view. 
The four objects of investigation, the constitutional debates in Germany, Britain, Sweden and Finland offer a convincing European mix of big and small, central and periphery, war winners, war losers and neutrals, connected and disconnected. One of the strengths of the book is the way in which Ihalainen both compares these countries and the historically founded political cultures that they constituted around 1918 at the same time as he is attentive to the transnationally shared situation that unified them. Nation states have as Ihalainen notes traditionally been regarded as natural units for historical analysis. By contrast, comparative, not to talk about transnational analyses of political processes in the past have remained rare, maybe a bit less in analyses of institutions than of ideas.

The Zeitgeist at the formative moment of both crisis and opportunities in the wake of the world war and the Russian revolution, was shared in Europe and unified the polities in a continental debate. At the same time the political perceptions and responses to the issues at stake varied under connection to domestic power relationships and historical legacies. National debates were transnationally interconnected. Ihalainen's comparison of similarities and differences in the responses to the challenges of the time is not as so often restricted to a comparison of the substance of four national boxes but pays also great attention to the transnational dimension of what they shared. The analysis maps a complex mix of borders between political cultures, and political preconditions and politics that transcend such borders.

An illustrative case in point is the extensive extra-parliamentary campaign for folkstyre in Sweden, rule by the people, i. e. Swedish for democracy, reflecting the revolutionary development in Germany under the motto of Volksherrschaft providing arguments for an irresistible European transition. The Swedish social democrats tried to monopolize the interpretation of the democracy concept, which was the concept paving the way towards the future, branding the political right as undemocratic. The right, on the other hand, emphasized the long history of Swedish folkstyre as being capable of solving national problems. When the conservatives referred to folkstyre their imaginary was the historical unity of the king and his people which was something very different from what the social democrats had in mind. Nevertheless a political compromise was negotiated in institutional terms in the late autumn of 1918 against the backdrop of a revolutionary situation and the awareness of the civil war in Finland during the first half of 1918.

The break-through of liberal democracy around 1920 in response to the radicalization of the mass societies mobilized for the war efforts was far from global as Wilson and Lening wanted to believe and it did not lead to a stable institutional setting in those cases where democracy did break through. After still another world war it broke through again as social and liberal democracy but only in a limited part of the world and only for a while. Today the issue at 
stake seems to be a choice between neoliberal market-compliant democracy or illiberal democracy. The latter category seems to be equal to authoritarianism. The fragility that Ihalainen demonstrates for the early years of lived democracy in a part of Europe remains. Therefore, his book develops a history that speaks to our own time.

The book is will written and argued, and rich on empirical details but not overwhelming. It reads well and is digestible. The cross references between the four national discourses underpin convincingly the argument about a European transnational discourse on democracy and parliamentarism, and at the same time it lays out national specificities. The demonstration of a European pattern despite the diversity is one of several strengths of the book. It is no doubt a major achievement shedding historical light on today's situation. 